\title{
2. 大阪大学における腹腔鏡検查成績の検討
}

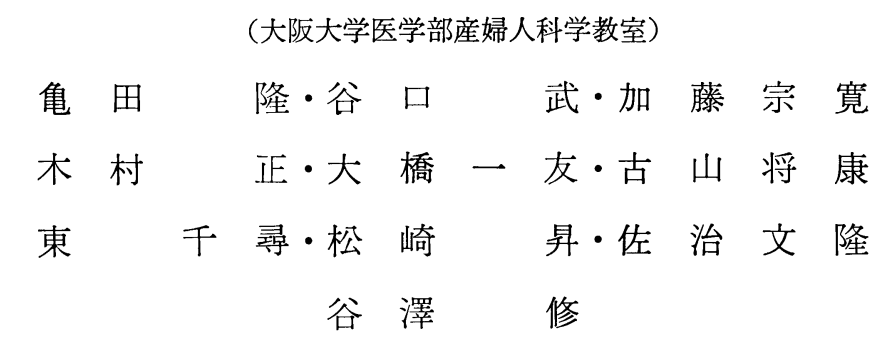

\section{緒 言}

腹腔鏡は，婦人科領域における検査および治療 手段の1つとして不可欠なるのとなった。我々 は，当科に拈ける腹腔鏡の主適応と診断およびそ の後の治療による妊娠を中心として報告を行っ た。

\section{対 象}

1985 年 10 月より 1989 年 12 月末までに, 当科 に执いて腹腔鏡を行った症例を対象とした，腹腔 鏡には Hasson による open type を用い，麻酔は插 管による全身麻酔とした，不妊症例には，生理食 塩水 $200 \mathrm{cc}$ による卵管内通水術を施行した.

\section{結果}

対象期間内に 254 例の腹腔鏡を施行した. この ちち 201 例は不妊症例, 53 例はそれ以外の症例で あった. 不妊症例のうち原発不妊 153 例, 続発不 妊 48 例で, 201 例の平均年齢は 32.4 歳, 平均不 妊期間は 3.4 年であった. 腹腔鏡を行った主適応 に関して，201例の不妊症では，原因不明不妊 110 例 $(54 \%)$ が最も多く, 次いで両側卵管閉塞 32 例 (16\%), 外性子宮内膜症 32 例 (16\%), 付属器周 囲癒着 27 例(13\%)の順であった。不妊症以外の 53 例の主適応は, 子宮内膜症の確定に行われた 36 例 $(68 \%)$ ) 最も多く, 次に子宮外妊娠の確定に 9 例 $(17 \%)$, 畉巣腫瘍の手術適応決定に 5 例 ( $9 \%$ ), その他急性腹症および内性器評価のために 3 例 (6\%)が行われた. 201 例の不妊症のらち, 卵管 性不妊症は 90 例で, 残る 111 例はそれ以外であ った，卵管性不妊症 90 例に対して，マイクロサ ージャリーによる卵管形成術が 36 例に行われ，
10 例 (28\%)が妊娠に成功した. 腹腔鏡下卵管周囲 癒着剃離術は 19 例に行われ 4 例 $(21 \%)$ が妊娠し た. また手術不能例や手術後疎通性の不十分な 7 症例に IVF-ET が行われ，4例(57\%)が妊娠 し た. 残る 28 例は治療待期中の症例であるが 1 例 ( $2 \%$ )が妊娠したにすぎなかった。 従って卵管性 不妊 90 例中 19 例 (21\%)が妊娠に成功した. 卵管 性以外の不妊症は 111 例認められたが，その治源 には開腹手術が 34 例に行われ 12 例(35\%)が妊娠 に成功した. 34 例の開腹手術の内訳は, チョコレ 一下囊腫摘除術 8 例, 子宮筋腫核出術 8 例, 子宮 奇形の修復術 1 例であった. 111 例中 77 例は, 腹腔内所見が軽微なまたはない症例で，腹腔鏡下 卵管通水術のみ行われたことになるが，12 例(16 $\%$ )がその後 1 年以内に妊娠に成功した. 不妊症 以外の 53 例の腹腔鏡後の猃断の 5 , 子宮内膜 症に関して術前 36 例が疑われたにもかかわらず, 術前診断どらりであったのは19 例にすぎなかっ た(正診率 $53 \%$ ). 子宮外妊娠の 9 例は，いづれも 術前診断どうりで，このらち 2 例は周囲との癒着 のため切除せざるを得なかったが， 7 例は保存手 術に成功した。 また腹腔鏡は, 卵巣腫痬や急性腹 症の診断と手術適応決定にも有用であった.

\section{結論}

我々は種々の婦人科疾患に腹腔鏡を応用し，そ の有用性を再確認した。不妊症に和いては, 卵管 性不妊とそれ以外の不妊の診断確定, 治療に際し ては卵管形成術また IVF-ET の選択または術式の 決定に有用であった。不妊症以外でも，子宮内膜 症, 子宮外妊娠叔よび急性腹症の診断に有用であ った. 